\title{
Karakteristik Beton Mutu Tinggi Dengan Komposisi Slag dan Agregat Halus Batu Gamping
}

\author{
Dicaprio Resen Bunga**1, Frans Phengkarsa *2, Desi Sandy*3 \\ *1 Mahasiswa Program Studi Teknik Sipil, Universitas Kristen Indonesia Paulus, Makassar \\ Email xxxdicaprio@gmail.com \\ *2 Dosen Program Studi Teknik Sipil, Universitas Kristen Indonesia Paulus, Makassar \\ Email fphengkarsa@hotmail.com \\ *3 Dosen Program Studi Teknik Sipil, Universitas Kristen Indonesia Paulus, Makassar \\ Email sandy mylife@gmail.com
}

\begin{abstract}
ABSTRAK
Pada umumnya agregat halus dan agregat kasar sebagai bahan komponen utama penyusun beton banyak berasal dari alam sehingga suatu saat akan habis, maka diperlukan bahan alternatif penggantinya. Salah satu bahan alternatif adalah Slag Nikel. Slag nikel merupakan sejenis batuan hasil pembuangan dari Industri nikel. Pemanfaatan batu gamping juga sebagai alternatif bahan pengganti agregat halus. Penelitian ini bertujuan untuk mengetahui kekuatan beton dan hubungan karateristik beton yang menggunakan Slag nikel dan batu gamping sebagai bahan pengganti agregat halus terhadap mutu beton. Adapun dengan variasi $0 \%, 10 \%$ dan $20 \%$ dan persentase penggunaan batu gamping sebagai bahan substitusi agregat halus sebesar $10 \%$.Metode pencampuran beton menggunakan metode SNI03-2834-2000 dengan mutu beton direncanakan 42Mpa. Dari hasil ini penelitian diperoleh nilai kuat tekan beton dengan variasi $0 \%, 10 \%$ dan $20 \%$ berturut-turut sebesar $42,360 \mathrm{MPa}, 42,347 \mathrm{MPa}$ dan $41,781 \mathrm{MPa}$, pengujian kuat tarik belah dengan variasi $0 \%, 10 \%$ dan $20 \%$ berturut-turut sebesar 3,94 MPa, $3.064 \mathrm{MPa}$ dan $2.293 \mathrm{MPa}$ dan pengujian kuat lentur dengan variasi $0 \%, 10 \%$ dan $20 \%$ berturut-turut sebesar 4,242 MPa, 4,068 MPa dan 3,179 MPa. Hubungan kuat tarik belah untuk variasi variasi Slag Nikel 0\%, 10\%, dan 20\% berturut-turut sebesar 9,242\%, 7,178\%, dan $7 \%$ dari kuat tekan, Hubungan kuat tarik belah untuk variasi variasi Slag Nikel $0 \%, 10 \%$, dan $20 \%$ berturut-turut sebesar $0,65 \sqrt{\mathrm{f}^{\prime} \mathrm{c}}$, $0,62 \sqrt{f^{\prime} c}$, dan $0,57 \sqrt{f^{\prime} c}$ dari kuat tekan. Dari hasil penelitian disimpulkan bahwa campuran beton dengan subtitusi slag nikel dan batu gamping mengakibatkan penurunan kekuatan seiring bertambahnya presentase subtitusi slag nikel.
\end{abstract}

Kata kunci :batu gamping,kuat tekan, kuat tarik belah, kuat lentur.

\section{ABSTRACT}

In general, fine aggregate and coarse aggregate as the main components of concrete come from nature so that one day it will run out, alternative substitutes are needed. One of the alternative materials is Nickel Slag. Nickel slag is a type of rock dumped from the nickel industry. Limestone is also used as an alternative to fine aggregate. This study aims to determine the strength of concrete and the relationship between the characteristics of the concrete using nickel slag and limestone as a substitute for fine aggregate to the quality of the concrete. As for the variations of $0 \%, 10 \%$ and $20 \%$ and the percentage of using limestone as a substitute for fine aggregate is $10 \%$. The method of mixing the concrete uses the SNI-03-2834-2000 method with a planned concrete quality of 42Mpa. From this research, it was found that the compressive strength of concrete with variations of $0 \%, 10 \%$ and $20 \%$ were respectively $42.360 \mathrm{MPa}, 42.347 \mathrm{MPa}$ and $41.781 \mathrm{MPa}$, the split tensile strength test with variations of $0 \%, 10 \%$ and $20 \%$ respectively was equal to $3.94 \mathrm{MPa}$, 3.064 MPa and $2.293 \mathrm{MPa}$ and the flexural strength testing with variations of $0 \%, 10 \%$ and $20 \%$ were respectively 4.242 $\mathrm{MPa}, 4.068 \mathrm{MPa}$ and $3.179 \mathrm{MPa}$. The relationship of split tensile strength for the variation of Nickel Slag variations $0 \%$, $10 \%$, and $20 \%$ is $9,242 \%, 7,178 \%$, and $7 \%$ of the compressive strength, respectively, the relationship of split tensile strength for the variation of Nickel Slag variations $0 \%, 10 \%$, and $20 \%$ of $0.65,0.62$, and 0.57 of compressive strength, respectively. From the results of the study, it was concluded that the concrete mixture with nickel and limestone slag substitution resulted in a decrease in strength as the percentage of nickel slag substitution increased.

Key words: limestone, compressive strength, split tensile strength, flexural strength

\section{PENDAHULUAN}

Perkembangan konstruksi di Indonesia terjadi begitu cepat, salah satunya adalah perkembangan teknologi beton yang merupakan satu hal yang tak dapat dipisahkan dari dunia konstruksi. Tidak hanya untuk bangunan gedung, kini beton juga dipakai untuk lapisan perkerasan pada konstruksi jalan. Hal ini menunjukkan bahwa pengunaan beton sudah mencakup seluruh bidang dalam infrastruktur dalam 
Paulus Civil Engineering Journal

Jurnal Teknik Sipil UKI-Paulus Makassar https://doi.org/10.52722/pcej.v3i2.3203

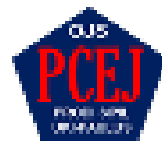

Volume 3 No.2, Juni 2021

e-ISSN 2775-4529

p-ISSN 2775-8613 upaya menunjang seluruh kegiatan manusia. Bangunan struktur seperti struktur jembatan, terowongan kereta api, bendungan, bangunan gedung bertingkat tinggi, memerlukan beton dengan mutu tinggi atau kuat tekan lebih dari 42 MPa.

Beton sendiri erat kaitannya dengan agregat agregat halus. Adapun agregat halus merupakan material yang berasal dari alam sehingga suatu saat akan habis. Adapun kita memerlukan bahan alternatif penggantinya untuk mengatasi hal tersebut.

Adapun bahan alternatif yang dapat digunakan sebagai material adalah Slag (Limbah Padat). Limbah nikel (Slag) merupakan sejenis batuan hasil limbah dari pembuatan nikel.. Selama ini Slag memiliki dampak negatif terhadap lingkungan karena belum bisa dimanfaatkan secara optimal. Dan pemanfaatan batu gamping sebagai alternatif bahan pengganti agregat halus.

Adapun tujuan dari penelitian ini adalah :

1. Mengetahui pengaruh kekuatan beton dengan uji kuat tekan, kuat tarik belah, dan kuat lentur dengan subtitusi slag dan batu gamping pada agregat halus.

2. Mengetahui Hubungan antara kuat tekan dengan kuat tarik belah dan kuat tekan dengan kuat lentur

Berdasarkan SNI 2847:2019, beton (Concrete) merupakan campuran antara agregat kasar, agregat halus, semen portland, dan air, dengan atau tanpa bahan tambahan. [1]

Slag memiliki kandungan Kalsium Oksida (Cao) dan Silikon dioksida (SiO2) yang tinggi yaitu $42,30 \%$ dan $26,56 \%$. Dalam hal ini $\mathrm{CaO}$ bebas dalam campuran beton akan bereaksi dengan air selama proses hidrasi menjadi $\mathrm{Ca}(\mathrm{OH}) 2$, reaksi ini akan membuat beton berkembang. [2]

Batu kapur atau yang biasa disebut batu gamping merupakan batuan sedimen non-klastik yang terbentuk dari proses kimia atau proses biologi. Kandungan utama batu gamping adalah mineral kalsium karnonat (CaCO3) yang terjadi akibat proses kimia dan organik. [3]

\section{Pengujian Beton}

Adapun pengujian beton yang dilakukan yaitu:

a. Pengujian kuat tekan beton

Berdasarkan SNI 1974:2011, Kuat tekan beton adalah besar kecilnya beban per satuan luas, beban tertentu yang ditimbulkan oleh alat uji tekanan akan menyebabkan benda (silinder) yang akan diuji roboh [4]

b. Pengujian kuat lentur beton

Berdasarkan SNI 4431:2011, mengacu pada kemampuan benda uji (batang) untuk menahan gaya vertikal sampel hingga sampel hancur [5]

c. Pengujian kuat tarik belah.

Kekuatan tarik mempunyai nilai besar dari kuat tarik langsung dan kurang dari kekuatan lentur. Adapun fungsinya dipakai untuk mengevaluasi kekuatan geser beton dan menentukan panjang rolling dari counterweight, (SNI 2491:2014). [6]

\section{METODE}

1. Pengadaan Material

a. Semen Portland Composite Cement (PCC) yang digunakan adalah produksi PT Semen Tonasa yang telah diperoleh dari toko bangunan terdekat yaitu toko UD. Cahaya Dury.

b. Agregat Kasar dan Agregat halus yang digunakan berasal dari Sungai Jeneberang, Sulawesi Selatan.

c. Pasir Gamping yang digunakan berasal dari Kecamatan Alla,Kabupaten Pangkep.

d. Air yang digunakan bersal dari sumur bor di Laboratorium Teknologi dan Bahan Beton Universitas Kristen Indonesia Paulus, Makassar.

e. Slag nikel yang digunakan berasal dari pabrik PT. Huadi Nickel yang berada Desa Papan Loe (berdekatan dengan Jalan poros Bantaeng Bulukumba ), Kota Bantaeng, Provinsi Sulawesi Selatan

\section{Persiapan Alat Penelitian}

a. Oven

b. Timbangan

c. Saringan/Ayakan

d. Mesin penggetar ayakan (shieve shaker)

e. Kerucut Terpancung (Cone) 
Paulus Civil Engineering Journal Jurnal Teknik Sipil UKI-Paulus Makassar https://doi.org/10.52722/pcej.v3i2.3203

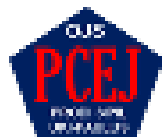

Volume 3 No.2, Juni 2021 e-ISSN 2775-4529 p-ISSN 2775-8613

f. Mesin Pencampur Bahan (mixer/molen)

j. Alat-alat Pendukung lainnya

g. Cetak Silinder $30 \times 15$

f. Cetak Balok $60 \times 15 \times 15$

g. Bak Perendaman

h. Kerucut Abrams

3. Pemeriksaan Karakteristik Material

i. Mesin Pengujian

a. Agregat Halus

Tabel 1. Pedoman karakteristik agregat halus

\begin{tabular}{|c|c|c|}
\hline Karakteristik & \multicolumn{2}{|c|}{ Pedoman } \\
\hline Kadar lumpur (\%) & \multicolumn{2}{|c|}{ SNI 03-4142-1996 } \\
\hline Kadar organik (warna) & \multicolumn{2}{|c|}{ SNI 2816-2014 } \\
\hline Kadar air (\%) & \multicolumn{2}{|c|}{ SNI 03-1971-2011 } \\
\hline Berat volume padat (kg/ltr) & \multicolumn{2}{|c|}{ SNI 03-4804-1998 } \\
\hline Berat volume gembur (kg/ltr) & \multicolumn{2}{|c|}{ SNI 03-4804-1998 } \\
\hline Penyerapan (\%) & \multicolumn{2}{|c|}{ SNI 1970-2008 } \\
\hline Berat jenis SSD & \multicolumn{2}{|c|}{ SNI SNI 1970-2008 } \\
\hline Analisa Saringan & \multicolumn{2}{|c|}{ SNI ASTM C136:2012 } \\
\hline \multicolumn{3}{|c|}{ Tabel 2. Hasil pengujian agregat halus } \\
\hline Karakteristik & Hasil & Interval SNI \\
\hline Kadar Air(\%) & 4,493 & $2,00-5,00$ \\
\hline Zat Organik & No.2 & $<$ No.3 \\
\hline Kadar lumpur (\%) & 2,300 & $0,20-6,00$ \\
\hline Berat Jenis SSD & 2,564 & $1,60-3,20$ \\
\hline Absorsi (\%) & 1,626 & $0,20-2,00$ \\
\hline Berat Volume Padat $\left(\mathrm{kg} / \mathrm{m}^{3}\right)$ & 1598,333 & $1400-1900$ \\
\hline Berat Volume Gembur $\left(\mathrm{kg} / \mathrm{m}^{3}\right)$ & 1473,333 & $1400-1900$ \\
\hline Modulus Kehalusan & 2,452 & $2,20-3,10$ \\
\hline
\end{tabular}

\section{b. Agregat Kasar}

Tabel 3. Pedoman karakteristik agregat kasar

\section{Karakteristik}

Kadar lumpur, \%

Kadar air, \%

Berat volume padat, (kg/ltr)

Berat volume gembur, (kg/ltr)

Absorpsi/Penyerapan (\%)

Berat jenis (SSD)

Analisa Saringan
Pedoman

SNI 03-4142-1996
SNI 03-1971-2011
SNI 03-4804-1998
SNI 03-4804-1998
SNI 1969-2008
SNI 1969-2008

Tabel 4. Hasil pengujian agregat kasar

\begin{tabular}{ccc}
\hline Karakteristik & Hasil & Interval SNI \\
\hline Kadar Air(\%) & 0,756 & $0,50-2,00$ \\
Kadar lumpur(\%) & 0,960 & $0,20-1,00$ \\
Berat Volume Padat $\left(\mathrm{kg} / \mathrm{m}^{3}\right)$ & 1606,667 & $1400-1900$ \\
Berat Volume Gembur(kg/ $\left.\mathrm{Im}^{3}\right)$ & 1555,556 & $1400-1900$ \\
Berat Jenis SSD & 2,694 & $1,60-3,20$ \\
Absorpsilpenyerapan (\%) & 1,875 & $0,20-2,00$ \\
\hline
\end{tabular}

\section{c. Pasir Gamping}

Tabel 5. Hasil pengujian pasir gamping 


\begin{tabular}{ccc}
\hline Karakteristik & Kadar Air (\%) \\
Zat Organik \\
Kadar Lumpur (\%) \\
Berat Jenis SSD \\
Absorpsi/Penyerapan (\%) \\
Berat Volume Padat $\left(\mathrm{kg} / \mathrm{m}^{3}\right)$ \\
Berat Volume Gembur $\left(\mathrm{kg} / \mathrm{m}^{3}\right)$ \\
Modulus Kehalusan
\end{tabular}

\section{Mix Design (SNI 03-2834-2000)}

Tabel 7. Komposisi Kebutuhan Bahan Campuran Beton Untuk $1 \mathrm{~m}^{3}$ dalam berat $(\mathrm{kg})$

\begin{tabular}{ccccccc}
\hline $\begin{array}{c}\text { Slag } \\
\begin{array}{c}\text { Nikel } \\
\%\end{array}\end{array}$ & Semen & Air & $\begin{array}{c}\text { Agregat } \\
\text { Kasar }\end{array}$ & $\begin{array}{c}\text { Agregat } \\
\text { Halus }\end{array}$ & $\begin{array}{c}\text { Slag } \\
\text { Nikel }\end{array}$ \\
\hline $0 \%$ & 609,5 & 193 & 1063,32 & 698,701 & - \\
$10 \%$ & 609,5 & 193 & 1063,32 & 621,067 & 77,633 \\
$20 \%$ & 609,5 & 193 & 1063,32 & 543,434 & 155,267 \\
\hline
\end{tabular}

\section{Trial Mix}

Pembuatan trial mix bertujuan untuk mengetahui komposisi dari hasil perhitungan Mix Design yang telah dihitung apakah memenuhi kuat tekan rencana $\left(f^{\prime} c\right)$. Dari hasil pengujian kuat tekan beton sampel trial mix menggunakan variasi pasir gamping $0 \%, 10 \%, 20 \%$ umur 3 dan 7 hari diperoleh nilai kuat tekan diatas kuat tekan rencana yaitu 42 $\mathrm{MPa}$. Jadi komposisi material untuk beton yang direncanakan tercapai.

\section{Pembuatan Benda Uji}

Proses membuat benda uji sesuai dengan aturan SNI Pd T-04-2004-C yaitu ; [7]

1. Pengadukan beton

Pengadukan beton sesuai komposisi dan ukuran Mix Design. sehingga terdapat sisa $10 \%$ lebih setelah memasukkan benda uji kedalam silinder.

2. Pengujian slump test dengan slump test rencana yaitu $75-100 \mathrm{~mm}$.

\begin{tabular}{cc} 
Hasil & Interval SNI \\
\hline 4,20 & $3,00-5,00$ \\
No.1 & $<$ No.3 \\
3,119 & $0,20-6,00$ \\
1,628 & $1,60-3,20$ \\
1,481 & $0,20-2,00$ \\
1,833 & $1400-1900$ \\
2,254 & $1400-1900$ \\
2,728 & $2,20-3,10$ \\
\hline
\end{tabular}

(a)

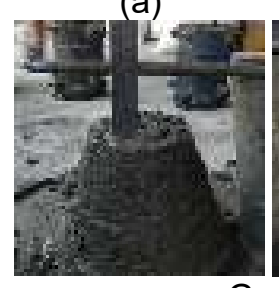

Gambar 1. Slump test (a) GP 10\% yaitu $8 \mathrm{~cm}$,

(b) GP $15 \%$ yaitu $8,5 \mathrm{~cm}$

(c) GP $20 \%$ yaitu $9 \mathrm{~cm}$.

3. Pencetakan benda uji harus sedekat mungkin dengan area penyimpanan selama 24 jam. Tempatkan cetakan pada permukaan yang kaku bebas getaran dan gangguan lainnya.

4. Identifikasi benda uji atau pemberian kode identifikasi benda uji.

\section{Perawatan Benda Uji}

Sampel yang sudah kering kemudian dikeluarkan dari cetakan, diberi kode dan diproses sesuai batas waktu perendaman dalam uji kekuatan beton. Untuk keperluan pemrosesan subjek tes:

a. Mencegah keretakan pada permukaan beton akibat uap air yang terlalu cepat menguap pada beton baru.

b. Dengan menstabilkan hidrasi semen, kemungkinan pencapaian kekuatan yang dibutuhkan meningkat.

\section{Pengujian Sifat Mekanik Beton}

\section{a. Kuat Tekan Beton}

Kuat tekan (SNI 1974:2011) dilakukan setelah proses perawatan dan masa pemeliharaan 7,21 , dan 28 hari. 
Paulus Civil Engineering Journal Jurnal Teknik Sipil UKI-Paulus Makassar https://doi.org/10.52722/pcej.v3i2.3203

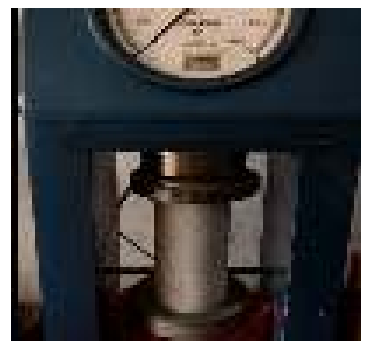

Gambar 2. Compression testing machine kapasitas $2000 \mathrm{KN}$

\section{b. Kuat Tarik Belah}

Kuat tarik beton (SNI 2491-2014) Pada umur 28 hari dilakukan pengujian kuat tekan pada benda

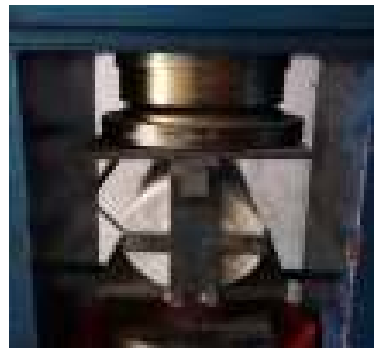

yang akan diuji.

Gambar 3. Pengujian kuat tarik belah beton

\section{c. Kuat Lentur Balok}

Tabel 8. Hasil pengujian kuat tekan beton pasir gamping $0 \%$

\begin{tabular}{|c|c|c|c|c|}
\hline $\begin{array}{l}\mathrm{U} \\
\mathrm{m} \\
\mathrm{u} \\
\mathrm{r}\end{array}$ & $\begin{array}{c}\text { Kode } \\
\text { Benda Uji }\end{array}$ & $\begin{array}{l}\text { Kuat Tekan } \\
\text { Aktual (MPa) }\end{array}$ & $\begin{array}{c}\text { Kuat Tekan Aktual } \\
\text { Rata-rata (MPa) }\end{array}$ & $\begin{array}{c}\text { Kuat Tekan } 28 \\
\text { Hari (MPa) }\end{array}$ \\
\hline 7 & $\begin{array}{l}1 \text { BKT1 } 7 \\
2 \text { BKT1 } 7 \\
3 \text { BKT1 } 7 \\
\end{array}$ & $\begin{array}{l}27,162 \\
32,821 \\
28,294\end{array}$ & 29,426 & 45,271 \\
\hline 21 & $\begin{array}{lll}1 & \text { BKT1 } 21 \\
2 & \text { BKT1 } 21 \\
3 & \text { BKT1 } 21 \\
\end{array}$ & $\begin{array}{l}39,046 \\
40,744 \\
40,461 \\
\end{array}$ & 29,630 & 42,193 \\
\hline 28 & $\begin{array}{l}1 \text { BKT1 } 28 \\
2 \text { BKT1 } 28 \\
3 \text { BKT128 }\end{array}$ & $\begin{array}{l}42,441 \\
41,310 \\
44,139\end{array}$ & 42,630 & 42,630 \\
\hline
\end{tabular}

Tabel 9. Hasil pengujian kuat tekan beton pasir gamping 10\%

\begin{tabular}{|c|c|c|c|c|}
\hline $\begin{array}{c}\mathrm{U} \\
\mathrm{m} \\
\mathrm{u} \\
\mathrm{r}\end{array}$ & Kode Benda Uji & $\begin{array}{c}\text { Kuat Tekan Aktual } \\
\text { (MPa) }\end{array}$ & $\begin{array}{c}\text { Kuat Tekan Aktual } \\
\text { Rata-rata (MPa) }\end{array}$ & $\begin{array}{c}\text { Kuat Tekan } \\
28 \text { Hari (MPa) }\end{array}$ \\
\hline 7 & $\begin{array}{l}\text { BKT2 } 7 \\
2 \text { BKT2 } 7 \\
3 \text { BKT2 } 7\end{array}$ & $\begin{array}{l}29,992 \\
28,577 \\
25,465\end{array}$ & 28,011 & 43,094 \\
\hline 21 & $\begin{array}{l}1 \text { BKT2 } 21 \\
2 \text { BKT2 } 21 \\
3 \text { BKT2 } 21\end{array}$ & $\begin{array}{l}36,217 \\
39,612 \\
36,782\end{array}$ & 37,537 & 39,513 \\
\hline
\end{tabular}




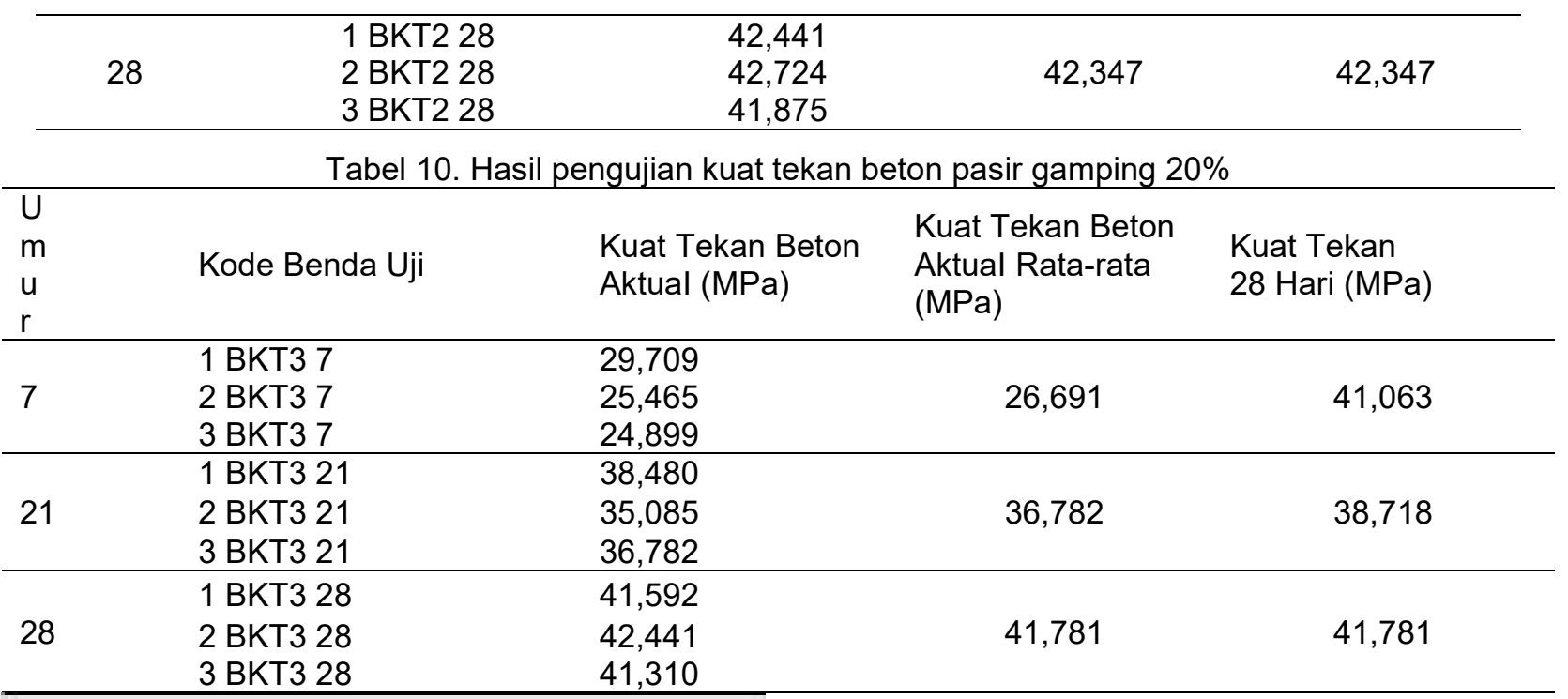

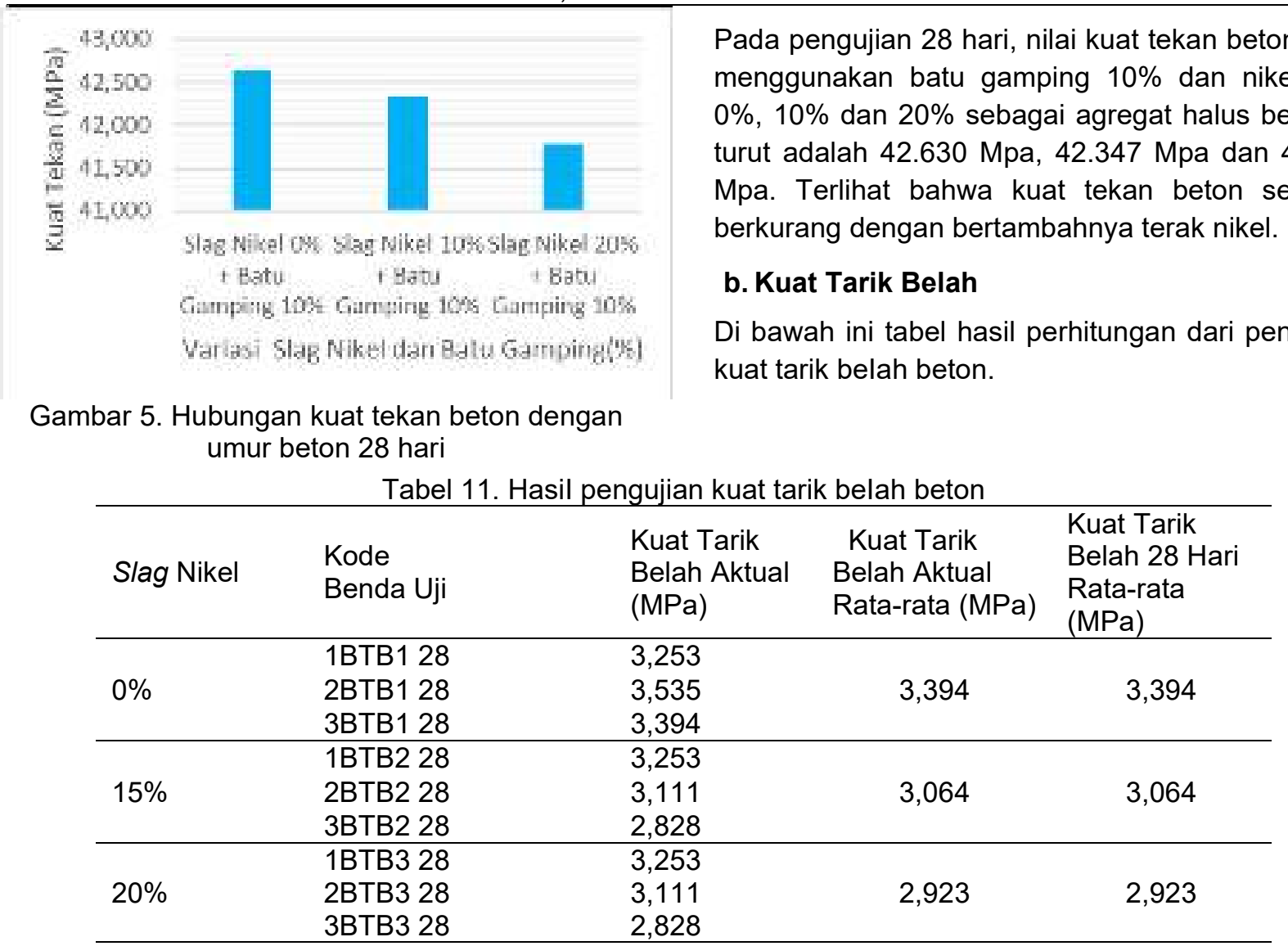




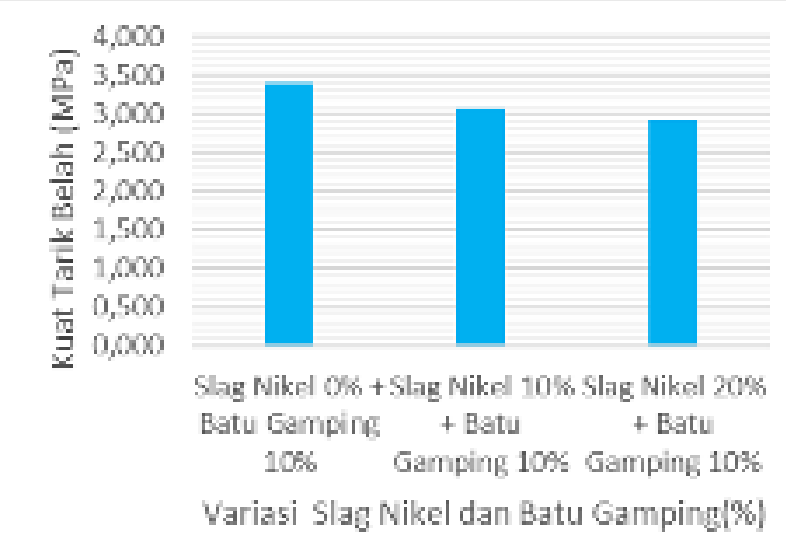

Gambar 6. Hubungan kuat tarik belah dengan variasi slag
Berdasarkan grafik pada gambar 15 menunjukkan nilai kuat tarik belah beton dengan substitusi batu gamping $10 \%$ dan Slag nikel 0\%, 10\%, dan 20\% berturut-turut sebesar 3,94 $\mathrm{MPa}, 3,064 \mathrm{MPa}$, dan 2,923 MPa. Dari hal tersebut dapat dilihat bahwa nillai kekuatan tarik belah beton menurun seiring bertambahnya variasi Slag nikel.

\section{c. Kuat Lentur Beton}

Tabel di bawah ini adalah hasil perhitungan dari pengujian kuat lentur beton.

Tabel 12. Hasil pengujian kuat lentur beton

\begin{tabular}{lllc} 
Slag Nikel & Kode Benda Uji & $\begin{array}{l}\text { Kuat Lentur Beton } \\
(\mathrm{MPa})\end{array}$ & $\begin{array}{l}\text { Kuat Lentur Beton Aktual } \\
\text { Rata-rata (MPa) }\end{array}$ \\
\hline \multirow{2}{*}{$0 \%$} & 1BKL1 28 & 4,533 & 4,242 \\
& 2 BKL12 28 & 4,010 & \\
\hline \multirow{2}{*}{$10 \%$} & 3 BKL1 28 & 4,184 & 4,068 \\
& 1BKL2 28 & 4,184 & \\
\hline \multirow{2}{*}{$20 \%$} & 2 BKL2 28 & 4,010 & 3.719 \\
& 3 BKL2 28 & 4,010 & \\
\hline
\end{tabular}

Hubungan antara Kuat Tekan dan Kuat Tarik

4,000

त๐ 3,500

$\sum 3,000$

2,500

2, 2000

बे 1,500

$\div 1,000$

蛋 0,500

0,000

Slag Nikel 0\% + Slag Nikel 10\% Slag Nikel 20\%

Batu Gamping + Batu Gamping+ Batu Gamping

$$
10 \% \quad 10 \% \quad 10 \%
$$

Variasi Slag Nikel dan Batu Gamping(\%)

Gambar 7. Hubungan variasi substitusi slag nikel dan kuat lentur beton

Berdasarkan grafik pada Gambar 7 menunjukkan nilai kuat lentur beton dengan substitusi batu gamping $10 \%$ dan Slag nikel $0 \%$, 10\%, dan $20 \%$ sebagai agregat halus berturut-turut sebesar 4,242 MPa, 4,068 MPa, dan 3,179 MPa. Dari hal tersebut dapat dilihat bahwa kuat lentur beton menurun seiring bertambahnya variasi Slag nikel.

\section{Beton}

Hubungan antara kuat tekan dan kuat Tarik dilakukan untuk mengetahui nilai persentase kuat tarik belah terhadap kuat tarik beton pada umur 28 hari untuk Slag Nikel $0 \%, 10 \%, 20 \%$ berturut-turut sebesar 42,630 MPa, 42,347 MPa, 41,781 MPa.. Kuat Tarik untuk GP 10\%,15\%,20\% berturut-turut sebesar 3,94 MPa, 3,04MPa, 2,923 MPa.

\section{Hubungan antara Kuat Tekan dan Kuat Lentur Beton}

Tabel 13. Perbandingan kuat tekan dengan kuat lentur

\begin{tabular}{|c|c|c|c|}
\hline \multirow[b]{2}{*}{$\begin{array}{c}\text { Kuat Tekan }\left(f^{\prime} c\right) \\
\text { [MPa] }\end{array}$} & \multirow{2}{*}{$\begin{array}{l}\text { Kuat } \\
\text { lentur } \\
(f r) \\
{[\mathrm{MPa}]}\end{array}$} & \multicolumn{2}{|c|}{ Perbandingan } \\
\hline & & $\sqrt{f^{\prime} c}$ & $\frac{f_{r}}{\sqrt{f^{\prime} c}}$ \\
\hline 42,630 & 4,242 & 6,529 & 0,65 \\
\hline 42,347 & 4,068 & 6,507 & 0,62 \\
\hline 41,781 & 3,719 & 6,463 & 0,57 \\
\hline
\end{tabular}


Paulus Civil Engineering Journal

Jurnal Teknik Sipil UKI-Paulus Makassar https://doi.org/10.52722/pcej.v3i2.3203

Sehingga diperoleh dari tabel diatas pada slag $0 \%$ nilai kuat lentur $0,65 \sqrt{ }\left(f^{\prime} \mathrm{c}\right)$ dari nilai kuat tekan, pada pada Slag $10 \%$ nilai kuat lentur $0,62 \sqrt{ }\left(f^{\prime} \mathrm{c}\right)$ dari nilai kuat tekan, dan pada slag $20 \%$ nilai kuat lentur $0,57 \sqrt{ }\left(f^{\prime} c\right)$ dari nilai kuat tekan. Nilai pada tabel tersebut telah memenuhi nilai korelasi kuat tarik dengan kuat tekan, dimana menurut Agus Setiawan (2016) pada umumnya kuat tarik belah berkisar antara $7 \%$ hingga $11 \%$ dari kuat tekannya. [8].

\section{KESIMPULAN}

Pengujian kuat tekan beton dengan variasi Slag nikel $0 \%, 10 \%$ dan $20 \%$ yaitu berturut-turut sebesar 42,630 Mpa, 42,347 Mpa, dan 41,781 Mpa. Pengujian kuat tarik belah beton dengan variasi Slag nikel $0 \%, 10 \%$ dan $20 \%$ yaitu berturut-turut sebesar 3,94 MPa, 3,064 MPa, dan 2,923 Mpa. .

Pengujian kuat lentur beton dengan variasi Slag nikel $0 \%, 10 \%$ dan $20 \%$ yaitu berturut-turut sebesar 4,242 MPa, 4,068 MPa, dan 3,179 MPa.

Hubungan kuat tekan putus masing-masing sebesar $9,242 \%, 7,178 \%$ dan $7 \%$ kuat tekan. Hubungan antara kuat lentur perubahan terak nikel sebesar $0 \%, 10 \%$ dan $20 \%$ berturut-turut adalah $0.65 \sqrt{ }\left(f^{\prime} c\right), 0.62 \sqrt{ }\left(f^{\prime} c\right)$ dan $0.57 \sqrt{ }\left(f^{\prime} c\right)$. ) Kekuatan tekan.

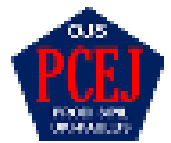

Volume 3 No.2, Juni 2021

e-ISSN 2775-4529

p-ISSN 2775-8613

\section{DAFTAR PUSTAKA}

[1] SNI 2847:2019, Persyaratan Beton Struktural Untuk Bangunan Gedung. Jakarta: Badan Standardisasi Nasional, 2019

[2] Adiwijaya, A., Datu, I. T., \& Khairil, K. 2018, "Penerapan Slag Baja Sebagai Pengganti Agregat pada Karakteristik Self Compacting Concrete". Jurnal Teknik Sipil Politeknik Ujung Pandang.

[3] Dunham, R. J., 1962, "Classification of carbonate Rock According To Depositional Textures" AAPG Memoir No.1

[4] SNI 03-4431-2011, Cara Uji Kuat Lentur Beton Normal dengan Dua Titik Pembebanan. Jakarta: Badan Standarisasi Nasional, 2011.

[5] SNI 1974-2011, Cara Uji Tekan Beton Dengan Benda Uji Silinder. Jakarta: Badan Standarisasi Nasional, 2011.

[6] SNI 4431:2011, Cara Uji Kuat Lentur Beton Normal Dengan Dua Titik Pembebanan. Jakarta: Badan Standardisasi Nasional, 2011.

[7] SNI 2491-2014, Metode Pengujian Kuat Tarik Belah Spesimen Beton Silinder. Jakarta: Badan Standardisasi Nasional, 2014.

[8] SNI Pd T-04-2004-C,Tata Cara Pembuatan Dan Perawatan Benda Uji Beton Di Laboratorium. Jakarta: Badan Standarisasi Nasional, 2004.

[9] Setiawan, Agus. 2016. Perancangan Struktur Beton Bertulang Berdasarkan. SNI 2847:2013. Jakarta: Erlangga, 2016. 